\title{
Control of Grasshoppers on Rangeland in the United States-A Perspective
}

\author{
GEORGE B. HEWITT AND JEROME A. ONSAGER
}

\begin{abstract}
The periodical ravages of locusts and grasshoppers have been sufficiently documented through history that it is easy to appreciate the seriousness of such outbreaks. We believe, however, that most people grossly underestimate the forage resources that are destroyed annually by typical "noneconomical" populations of grasshoppers.

The western range comprises about 262 million ha, most of which is suitable habitat for grasshoppers. The grasshoppers annually destroy at least $21-23 \%$ of available range vegetation. That would represent a loss of about $\$ 393$ million/year if that vegetation could otherwise be utilized by livestock. Current control measures are not economical on about 80 million ha because treatment cost far exceeds the value of forage that is produced. Most control programs are likely to be executed on about 160 million ha that produce forage worth about $\$ 2.50$ - $\$ 7.50 / \mathbf{h a}$.

Significant forage destruction begins during the 3rd nymphal instar. This occurs just before maturation of many important species of grass. Thus, grasshoppers do not generally inhibit forage production; rather, they hasten decomposition of the standing crop of forage. When control measures become necessary, they should be initiated as soon as possible after the majority of grasshoppers become 3 rd instars. Later trea tments cannot recover forage that has already been destroyed; they simply prevent further destruction.
\end{abstract}

Grasshoppers have been recognized as a problem on rangeland in the western United States since the first settlers planted crops and grazed domestic livestock. At certain times in history, such as the late 1800's and early 1900's, grasshoppers caused extensive damage to both crops and grasslands. Significant forage and crop losses still occur in spite of control measures by government agencies and individual ranchers. For example, in 1979, grasshoppers were the most widespread and caused the most damage since the major outbreaks of the late 1930's. From 1941 to 1978 , grasshopper populations fluctuated from year to year but each year losses occurred in many areas of the West. This problem is of great concern both to ranchers whose livestock must compete with grasshoppers for grazing privileges and to government personnel who are responsible for decisions regarding grazing management and insect control effects.

This paper gives a perspective of forage destruction on western rangeland by grasshoppers. An attempt is made to show how the problem has been approached in past years, as well as to show that the potential for forage losses is as great today as in the past. It is written for scientists, extension personnel, and range managers to provide a rational basis for decisions concerning research and management policies.

\section{Grasshopper Life History and Ecology}

About 600 species of grasshoppers occur within the United States. Only about a dozen species frequently occur in high densities on rangeland, but one or more of these major pest species occur in every major range ecosystem; an additional dozen species occa-

Authors are stationed at the Rangeland Insect Laboratory, USDA-ARS, Bozeman, Mont. 59717. sionally occur in high densities (Hewitt 1977). Some species such as Hypochlora alba (Dodge) and Hesperotettix viridis (Thomas) feed on undesirable plants and may be considered beneficial. However, the majority of species consume and destroy valuable grasses and forbs, and thereby compete with livestock and wildlife.

Most grasshoppers lay eggs in the fall. An extended warm fall with moist surface soil favors egg deposition. The eggs overwinter in diapause and hatch the following spring, usually beginning in late April in southern states and in late May in northern states. The time of hatching can be predicted by monitoring egg development in the fall and soil or air temperature in the spring (Randell and Mukerji 1974, Gage et al. 1976, Mukerji et al. 1977, Hewitt 1979), but such surveys are expensive and time consuming. Time of hatching can also be associated with development of key indicator plants (Hewitt 1980). However, a reliable and economical method for predicting spring grasshopper populations is not available.

Hatching takes place over a period of several weeks. While one species of potential economic importance, Aeropedellus clavatus (Thomas), is among the first to appear in the spring, and another, Phoetaliotes nebrascensis (Thomas), is among the last, most economic species occupy a median niche within the hatching period. Control measures therefore should be applied late enough to expose the majority of hatchlings but early enough to prevent major forage destruction. These are conflicting goals, so the use of a short-lived insecticide requires some compromise.

Most common rangeland grasshoppers go through 5 nymphal instars before the final molt to the adult stage. Each instar requires approximately 1 week. Adults become sexually mature in 10-14 days and commonly live as reproductive individuals for about 3 weeks. Under ideal conditions, senescent individuals may live for an additional $4-6$ weeks. The potential lifespan of grasshoppers may therefore total 14-16 weeks after hatching; the actual lifespan in nature, however, is subject to several important moderating factors.

Mortality is typically high during the egg stage and the first 2 nymphal instars, and direct mortality may occur at catastrophic levels if hatching is followed by several days of freezing temperatures. High relative humidity can cause extensive epizootics of a fungus disease, Entomophthora grylli. The potential of a threatening infestation therefore cannot be accurately assessed until most of the grasshoppers have developed to the 3rd nymphal instar. During and following the 3rd instar, the probability of catastrophic mortality becomes greatly reduced and other less intense mortality factors assume prominence. These include insect parasites and predators, birds, and other pathogens.

In a 3-year study near Roundup, Mont., the average longevity for 6 important species of rangeland grasshoppers was 7.1-10.5 days per nymphal instar and 12.1-21.4 days for the adult stage (Onsager and Hewitt 1982). In an experiment near Sheridan, Wyo., the longevity of mixed populations of late-instar grasshoppers at 20 rangeland sites was found to be inversely related to density (Onsager et al. 1980). Average longevity of the 4th and 5th instar nymphal plus adult stages ranged from about 95 days at 1 grasshopper $/ \mathrm{m}^{2}$ to only 25 days at 30 grasshoppers $/ \mathrm{m}^{2}$. Observed population decay curves for high, moderate, and low density popu- 
lations were similar to the hypothetical example shown in Figure 1. The incidence of predators and parasites tended to be directly proportional to densities of grasshoppers, so it was assumed that the reduced longevity in dense infestations was at least partially a result of those density-dependent causes of mortality.

\section{Effects of Grazing by Grasshoppers}

Grasshoppers have chewing mouth parts and graze in much the same manner as livestock, except $1 / 3$ to $1 / 2$ of the severed plant material falls to the ground as litter (Mitchell and Pfadt 1974). Some species prefer forbs, some prefer grasses, and some are omnivorous (Mulkern 1967). In general, most economic species tend either to be omnivorous (especially the early instars) or to prefer grasses. Laboratory data suggest that some grazing by grasshoppers may be beneficial in that regrowth was stimulated (Dyer and Bokhari 1976). In the field, however, heavy grazing can destroy entire plants or large portions of plants, thereby reducing photosynthetic area, inhibiting vegetative production, and reducing root reserves (Burleson and Hewitt 1982). Overgrazing by grasshoppers therefore can be at least as serious as overgrazing by livestock.

The amount of forage consumed and wasted by grasshoppers tends to increase with increasing stages of development (Hewitt 1978). The first 2 nymphal instars are generally of little consequence because they destroy very little forage compared to later instars and they occur early in the season when conditions are generally favorable for plant growth. The 3rd instar tends to become important for 3 major reasons: (1) it begins to consume significant amounts of forage, (2) its appearance coincides with maturation of several important cool-season grasses so most of the forage that is consumed will not be replaced by regrowth, and (3) the probability of catastrophic mortality becomes relatively low (Hewitt 1979). This relationship is shown in Figure 2. Late-insta nymphs and adult grasshoppers consume or waste an average of $44.3 \mathrm{mg}$ of rangeland forage per day (Hewitt 1977).

Seasonal grazing pressure has been estimated by calculating the cumulative number of grasshoppers that fed for 1-day intervals within an area, a unit that was referred to as a "grasshopper feeding day," abbreviated GFD (Hewitt et al. 1976). Assuming an initial density of 30 late-instar grasshoppers $/ \mathrm{m}^{2}$ and an average longevity of 25 days, the GFD $/ \mathrm{m}^{2}$ for the season can be calculated as $30 \times 25=750$. The method is illustrated in Figure 3, in which GFD equals the area under the curve. Figure 3 is only an approximation because density decay curves are exponential rather than lineal (Onsager and Hewitt 1982). However, Hewitt et al. (1976) and Onsager (1978) found that the relatively simple lineal relationship was adequate for describing natural populations that contained a mixture of late instars and adults.

The seasonal distribution of the GFD's is of extreme significance to a grasshopper control program. The amount of forage that is destroyed (most of which is not replaced) for each weekly interval after grasshoppers become 4 th instars can be estimated as a pro-

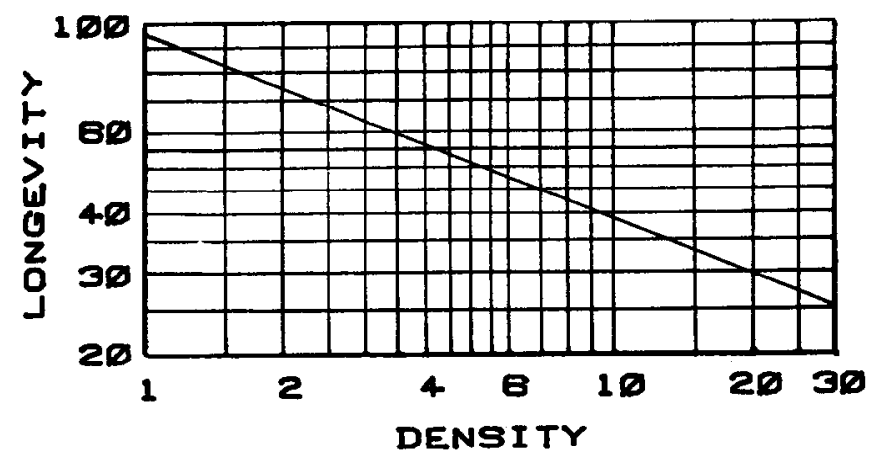

Fig. 1. Relationship between average density of grasshoppers $/ \mathrm{m}^{2}(X)$ and average days of longevity $(Y)$ in 20 untreated sites on rangeland (In $Y=$ $4.56-0.396 \ln X)$.

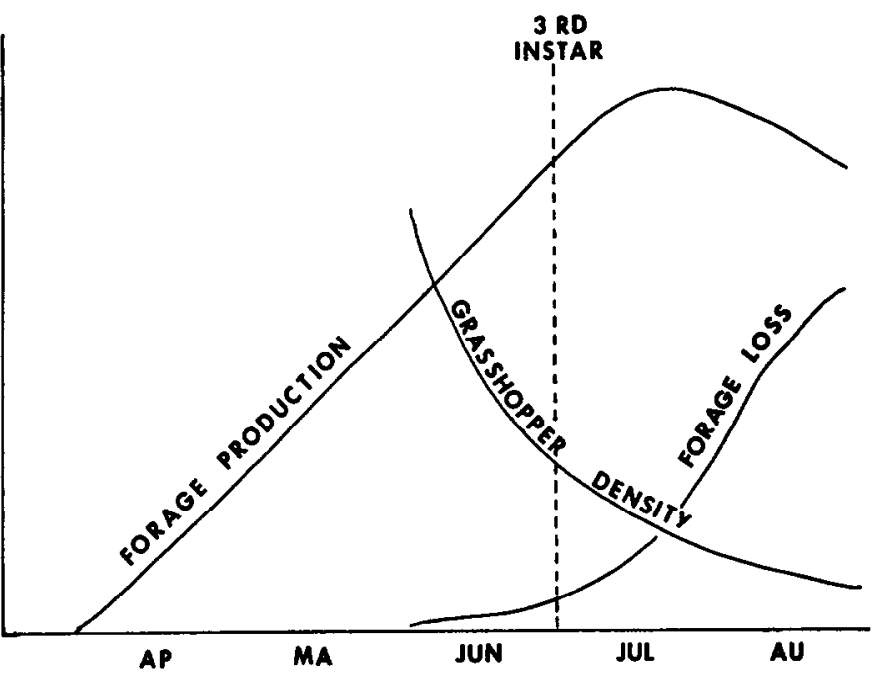

Fig. 2. Forage production and forage lost as a result of grasshopperfeeding in relation to grasshopper development and density.

portion of the total area under the curve. Thus, in Figure 3, approximately 26,22 , and $18 \%$ of the total seasonal forage destruction is caused by predominantly 4th- and 5th-instar nymphs and adults, respectively, during the first 3 weeks of the 50-day period. In other words, if control measures are delayed until grasshoppers are predominantly adults, perhaps $50 \%$ of their potential forage destruction will have already taken place.

\section{Grasshopper Habitats}

Rangeland can be described as land devoted to the production of predominantly native forage that is harvested by grazing animals. Rangeland comprises about 262 million ha west of the Mississippi River (USDA 1978). Grasslands and pasture comprise 227 million ha, and 36 million ha of grazable land are located within the western national forests (USDA 1978, Clapp 1936). An additional 21 million ha of cropland occasionally are used for pasture but grasshoppers generally are not a problem in intensively managed pasture. Rangeland grasshoppers are common and cause forage losses in 17 of the 22 western states. Only 5 states west of the Mississippi River (Minnesota, lowa, Missouri, Arkansas, and Louisiana) generally do not have consistent problems with grasshoppers on rangeland.

Rangelands vary from prairie grasslands to alpine meadows and

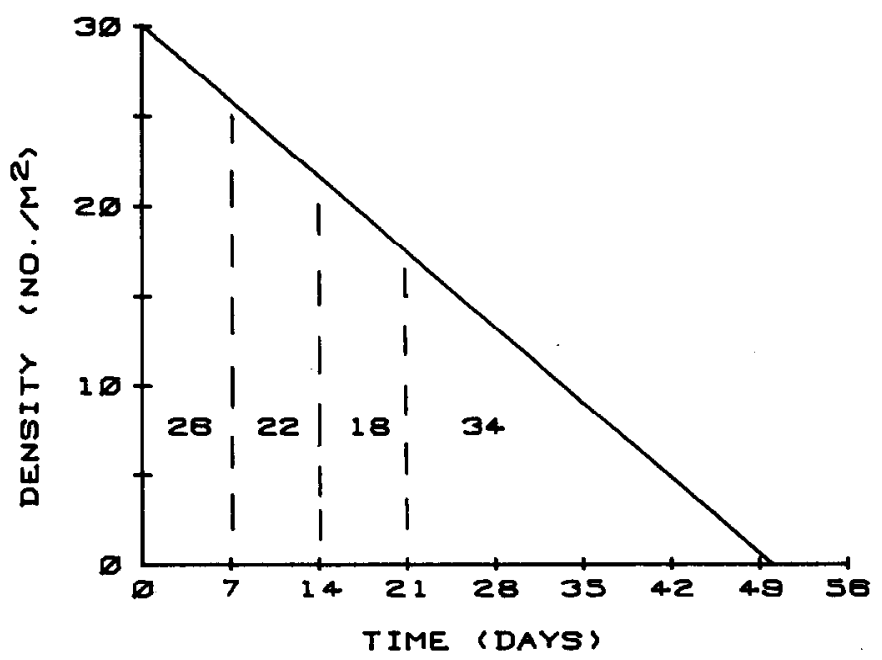

Fig. 3. Hypothetical relationship between density and time for an initial infestation of thirty 4 th-instar grasshoppers/ $\mathrm{m}^{2}$ (values within the figure indicate percentages of total area under the curve, which are equivalent to percentages of forage destruction with time). 
from deserts in the Southwest to open forests in the Rocky Mountains. Some ranges are grazed during the entire year, some during midsummer, some during spring and fall, and some during the winter. Grasses are the most important source of forage on western rangeland. Cool-season grasses dominate much of the northern United States and warm-season species dominate much of the southern area, but some areas have both types. Grasshoppers occur on all types of rangeland but are generally of greatest economic importance in areas dominated by grasses and forbs where the annual precipitation is less than $60 \mathrm{~cm}$. A summary of the location and extent of rangeland ecosystems in 17 western states is given in Table 1.

The grasslands of the Great Plains provide choice habitat for many economic grasshopper species. This ecosystem extends from Canada to Mexico, just east of the Rocky Mountains, in a belt about $800 \mathrm{~km}$ wide. The Great Plains occupy parts or entire area s of 10 states: Montana, Wyoming. Colorado, New Mexico, North Dakota, South Dakota, Nebraska, Kansas, Oklahoma, and Texas. The intermountain area lies between the Rocky Mountains and the Sierra Nevada and Cascade Range, and is broken by mountain ranges, valleys, and deserts. The dominant vegetation may be mountain or desert shrubs, pinyon-juniper areas, mountain grasslands, or sagebrush areas. The remaining rangeland lies primarily west of the Sierra Nevadas in California and consists of annual grasslands or desert shrubs. Grasshoppers are found in all of these areas, but highest densities are usually associated with areas where grasses and forbs predominate. For example, high grasshopper populations are seldom found within areas of dense sagebrush, but the sagebrush ecosystem does support higher grasshopper populations where grass comprises a higher percentage of the ground cover.

\section{Potential Forage Losses}

The average forage production on western rangeland is difficult to determine. Production is regulated largely by precipitation and soil moisture, and it varies greatly among and within ecosystems. Variations in production are also a result of interactions between many factors such as soil depth and fertility, plant species, grazing practices, and range condition.

Forage destruction by infestations of grasshoppers is a complex function of grasshopper density, species composition, feeding rates, and a verage longevity. Density and species composition are readily estimated by sampling. A number of feeding studies have been summarized by Hewitt (1977), and the reported average feeding rate of $44.3 \mathrm{mg} / \mathrm{GFD}$ is satisfactory for this discussion. Longevity is the least predictable of the $\mathbf{4}$ factors, but a conservative estimate is 25 days for 4 th and 5 th instar nymphs plus adults. Thus, for each grasshopper $/ \mathrm{m}^{2}$ over an area of $1 \mathrm{ha}$, the seasonal forage destruction is at least $44.3 \times 10^{-6} \mathrm{~kg} / \mathrm{GFD} \times 25 \mathrm{GFD} / \mathrm{m}^{2} \times$ $10000 \mathrm{~m}^{2} / \mathrm{ha}=11.08 \mathrm{~kg} / \mathrm{ha}$.

The average seasonal density of grasshoppers on rangeland also is difficult to determine. Densities of $30-40 / \mathrm{m}^{2}$ a re not uncommon and yet some areas of rangeland seldom have densities of more than $1 / \mathrm{m}^{2}$. Results from rangeland survey work conducted by personnel of the Bureau of Entomology and Plant Quarantine from 1936 to 1952 showed the average density to be 4.6 grasshoppers $/ \mathrm{m}^{2}$ (unpublished data by Frank T. Cowan; on file at the Rangeland Insect Laboratory). This average includes 5 years of outbreak conditions (1936-1940) during which losses were extremely high and 12 years (1941-1952) during which densities were lower than normal. An average loss of $51 \mathrm{~kg} / \mathrm{ha}$ was obtained by multiplying the average density $\left(4.6 / \mathrm{m}^{2}\right)$ times the loss caused by 1 grasshopper $/ \mathrm{m}^{2}$ over a ha $(11.08 \mathrm{~kg})$. Thus the yearly average estimated loss for the 262 million ha of western rangeland would be 13.35 million metric tons. An additional 5 million animal units could be grazed on the forage lost to grasshoppers if it is assumed that each animal unit consumes $2700 \mathrm{~kg}$ of forage (a maintenance diet of $9 \mathrm{~kg} /$ day for a grazing season of 300 days) (Bell 1973).

Table 1. Land area, stocking rates, and value of forage produced on range ecosystems. (An elaboration of data from USDA: Forest Service. 1972. The Nations Range Resources-Forest-Range Environmental Study. Forest Resource Report \#19. 147 p.)

\begin{tabular}{|c|c|c|c|c|c|c|c|c|c|c|c|c|c|c|c|}
\hline \multirow[b]{2}{*}{ State } & \multicolumn{14}{|c|}{ Land area (thousands of ha) by ecosystem } & \multirow[b]{2}{*}{$\begin{array}{c}\text { Total } \\
\text { ha } \\
\text { of } \\
\text { vs range }\end{array}$} \\
\hline & Alpine & $\begin{array}{c}\text { Desert } \\
\text { shrub }\end{array}$ & $\begin{array}{l}\text { Pinyon- } \\
\text { juniper }\end{array}$ & $\begin{array}{c}\text { South- } \\
\text { western } \\
\text { shrub- } \\
\text { steppe }\end{array}$ & $\begin{array}{c}\text { Cha parral } \\
\text { mountain } \\
\text { shrub }\end{array}$ & $\begin{array}{l}\text { Sage- } \\
\text { brush }\end{array}$ & $\begin{array}{c}\text { Desert } \\
\text { grass- } \\
\text { lands }\end{array}$ & $\begin{array}{l}\text { Shin- } \\
\text { nery }\end{array}$ & $\begin{array}{c}\begin{array}{c}\text { Moun- } \\
\text { tain } \\
\text { grass- } \\
\text { lands }\end{array} \\
\text { land }\end{array}$ & $\begin{array}{c}\text { Plains } \\
\text { grass- } \\
\text { lands }\end{array}$ & $\begin{array}{r}\text { Texas } \\
\text { savanna }\end{array}$ & Prairie & $\begin{array}{c}\text { Annual } \\
\text { grass- } \\
\text { lands }\end{array}$ & $\begin{array}{c}\text { Moun- } \\
\text { tain } \\
\text { mea- } \\
\text { dows }\end{array}$ & \\
\hline Ariz. & 81 & 7,263 & 3,425 & 5,495 & 1,987 & 400 & 2,562 & & 2,507 & & & & & 4 & 23,725 \\
\hline Calif. & 612 & 3,466 & 737 & & 5,529 & 1,194 & & & 1,739 & & & & 2,713 & 343 & 16,334 \\
\hline Colo. & 847 & 301 & 2,195 & & 894 & 1,603 & & & 2,544 & 5,875 & & 328 & & 265 & 14,851 \\
\hline Ida. & 360 & 110 & 159 & & 480 & 5,538 & & & 2,307 & & & & & 194 & 9,148 \\
\hline Kans. & & & & & & & & & & 4,906 & & 902 & & & 5,808 \\
\hline Mont. & 262 & 405 & $<1$ & & 342 & 2,375 & & & 5,276 & 12,617 & & & & 215 & 21,493 \\
\hline Neb. & & & & & & & & & & 3,895 & & 5,784 & & & 9,680 \\
\hline Nev. & 1 & 8,634 & 1,830 & & 1,146 & 11,031 & 28 & & 3,011 & & & & & 5 & 25,687 \\
\hline N. Mex. & 31 & 1,825 & 3,462 & 3,081 & 1,137 & 694 & 5,476 & 130 & 3,856 & 6,303 & & & & 140 & 26,137 \\
\hline N. Dak. & & & 4 & & 5 & & & & & 4,613 & & 237 & & & 4,859 \\
\hline Okla. & & & & & & & & 148 & & 4,418 & & 493 & & & 5,060 \\
\hline Ore. & 288 & 396 & 716 & & 156 & 5,291 & & & 3,235 & & & & & 100 & 10,182 \\
\hline S. Dak. & & & & & 21 & 8 & & & 55 & 8,772 & & 916 & & I & 9,775 \\
\hline Texas & & 6,589 & 18 & 7,057 & 89 & & 977 & 532 & & 11,554 & 6,164 & 6,540 & & & 39,521 \\
\hline Utah & 205 & 3,941 & 4,736 & & 807 & 2,522 & 1,526 & & 2,630 & & & & & 66 & 16,433 \\
\hline Wash. & 250 & & & & 109 & 671 & & & 2,498 & & & & & 83 & 3,610 \\
\hline Wyo. & 432 & 1,917 & 2 & & 290 & 6,829 & & & 2,676 & 7,216 & & & & 223 & 19,587 \\
\hline $\begin{array}{l}\text { Total } \\
\text { Domestic g } \\
\quad 1970(1,0\end{array}$ & $\begin{array}{l}3,370 \\
\text { razing, } \\
00\end{array}$ & 34,847 & 17,284 & 15,633 & 12,993 & 38,159 & 10,570 & 812 & 32,335 & 70,170 & 6,164 & 15,200 & 2,713 & 1,638 & 261,890 \\
\hline AUM's) & 33 & 1,742 & 1,715 & 1,958 & 1,957 & 10,850 & 5,073 & 456 & 21,441 & 50,454 & 5,042 & 36,814 & 7,003 & 4,309 & 148,848 \\
\hline $\begin{array}{r}\text { Average sto } \\
\text { rate (AU }\end{array}$ & $\begin{array}{l}\text { cking } \\
\text { M's/ }\end{array}$ & & & & & & & & & & & & & & \\
\hline ha) & 0.01 & 0.05 & 0.10 & 0.12 & 0.15 & 0.27 & 0.47 & 0.57 & 0.67 & 0.72 & 0.82 & 2.37 & 2.59 & 2.62 & 0.57 \\
\hline $\begin{array}{l}\text { Average } \\
\text { value (\$) }\end{array}$ & forage & & & & & & & & & & & & & & \\
\hline ha) & 0.10 & 0.44 & 0.89 & 1.14 & 1.36 & 2.57 & 4.32 & 5.06 & 5.95 & 6.47 & 7.36 & 21.36 & 23.39 & 23.63 & 5.11 \\
\hline
\end{tabular}


The average value of the forage produced in 1977 was determined to be $\$ 29.44 /$ metric ton. This was calculated from production and value data for cattle and sheep produced in the United States in 1977 (USDA 1978). The average price $/ \mathrm{kg}$ for both classes of livestock was determined to be $\$ 0.8832$ in 1977 . About $30 \mathrm{~kg}$ of forage is required to produce $1 \mathrm{~kg}$ of gain on a mature cow (Bell 1973); thus, 1 ton of forage would produce $33.3 \mathrm{~kg}$ of gain. The value of forage is no greater than the meat it produces so the value of 1 ton of forage is $(\$ 0.8832 \times 33.3)=\$ 29.44$. At this rate, the average dollar value of the annual forage loss on 262 million ha of western rangeland would be about $\$ 393$ million.

A summary of past stocking rates and estimated forage value for rangeland ecosystems is given in Table 1 . Total utilization can be estimated by adding forage utilized by livestock plus that utilized by grasshoppers. At $342 \mathrm{~kg} /$ animal unit month (AUM), $50.9 \mathrm{mil}-$ lion tons were harvested livestock. The 13.35 million tons estimated destroyed by grasshoppers, therefore, is at least $21 \%$ of all forage that was consumed. In terms of dollars, the total value of 148.8 million AUM's in Table 1 was about $\$ 1.34$ billion. Since forage worth $\$ 393$ million was destroyed by grasshoppers, at least $23 \%$ of the total forage value was devoted to production of grasshoppers. These estimates probably are quite conservative. We believe that the assumed longevity and feeding rate were provided by valid experiments, but the data were obtained from infestations that were well in excess of our assumed average of $4.6 / \mathrm{m}^{2}$ over the western range. Because sparse populations tend to live longer and therefore would consume more forage per individual, we are confident that our estimates do not exaggerate the seriousness of the situation. However, forage lost to grasshoppers has economic implications only if that forage was intended for other purposes.

\section{Objectives and History of Grasshopper Control Programs}

The cooperative grasshopper control program executed by USDA's Animal and Plant Health Inspection Service (APHIS) is intended to suppress economic grasshopper infestations on rangeland to protect range vegetation or prevent large-scale movement to susceptible crops. If the objective of a control program is to save available forage for consumption by livestock, then it is important that treatment be applied as soon as possible after predominant pest grasshoppers reach the 3 rd instar. Later treatments cannot recover forage that has already been lost but are able only to prevent further losses. This does not imply that late treatments applied to adult grasshoppers cannot be efficacious under some conditions. They may save forage that is worth as much or more than the cost of treatment, but under those conditions, early treatments probably would have been even more efficacious. Late treatments may also prevent egglaying and thereby reduce forage losses in subsequent seasons. However, Blickenstaff et al. (1974) reported no evidence of protection beyond the year of application in 7 of 9 cases studied, either because of rapid reinvasion of treated

Table 2. Approximate hectares (in thousands) sprayed for grasshopper control by APHIS in 17 western states."

\begin{tabular}{|c|c|c|c|c|c|c|c|c|c|c|c|c|}
\hline State & 1956 & 1957 & 1958 & 1959 & 1960 & 1961 & 1962 & 1963 & 1964 & 1965 & 1966 & 1967 \\
\hline Ariz. & 47 & 47 & 56 & 0 & 0 & 0 & 0 & 0 & 4 & 2 & 0 & 0 \\
\hline Calif. & 6 & 68 & 2 & $<1$ & 3 & 4 & 2 & 6 & 1 & $<1$ & 3 & $<1$ \\
\hline Colo. & 95 & 2 & 878 & 0 & 0 & 0 & 0 & 6 & 0 & 0 & 0 & 0 \\
\hline Ida. & 33 & 33 & 36 & 28 & 0 & 0 & 0 & 25 & 183 & 171 & 221 & 0 \\
\hline Kans. & 45 & & 52 & 36 & 0 & 0 & 0 & 0 & 0 & 0 & 0 & 0 \\
\hline Mont. & 12 & 22 & 94 & 11 & 16 & 5 & 161 & 5 & 2 & 66 & 157 & 225 \\
\hline Neb. & & & 42 & 17 & 0 & 0 & 0 & 0 & 0 & 4 & 0 & \\
\hline Nev. & 6 & 8 & 6 & 3 & $<1$ & 0 & 1 & 2 & 2 & 0 & 0 & 0 \\
\hline N. Mex. & 273 & 177 & 60 & 111 & 0 & 0 & 0 & 0 & 0 & 0 & 4 & 160 \\
\hline N. Dak. & $<1$ & & 22 & 0 & 5 & 2 & 32 & 3 & 0 & 0 & 0 & 0 \\
\hline Okla. & 90 & & 98 & 0 & 0 & 0 & 0 & 0 & 0 & 7 & 0 & 9 \\
\hline Ore. & & 0 & 0 & 0 & 0 & & 9 & 0 & 5 & 0 & 21 & 0 \\
\hline S. Dak. & 3 & & $<1$ & 3 & 28 & $<1$ & 0 & 1 & 0 & 14 & 0 & 0 \\
\hline Texas & 115 & & 377 & 0 & 0 & 0 & 0 & 0 & 0 & 0 & 39 & 26 \\
\hline Utah & $<1$ & 17 & 12 & 0 & 36 & $<1$ & 6 & 6 & $<1$ & 7 & 36 & 4 \\
\hline Wash. & & 0 & 0 & 0 & 0 & 0 & 0 & 0 & 0 & 0 & 0 & 0 \\
\hline Wyo. & 109 & 188 & 2 & 122 & 94 & 0 & 13 & 11 & 58 & 91 & 158 & 34 \\
\hline Total & 836 & 562 & 1,737 & 332 & 183 & 12 & 224 & 66 & 254 & 363 & 640 & 459 \\
\hline
\end{tabular}

'Blanks are missing data.

\begin{tabular}{|c|c|c|c|c|c|c|c|c|c|c|c|c|}
\hline 1968 & 1969 & 1970 & 1971 & 1972 & 1973 & 1974 & 1975 & 1976 & 1977 & 1978 & 1979 & Total \\
\hline 0 & 5 & 27 & 0 & 0 & 0 & 2 & 32 & 80 & 43 & 18 & 66 & 428 \\
\hline 0 & 6 & 3 & 11 & 1 & 0 & 1 & $<1$ & $<1$ & 0 & $<1$ & 2 & 121 \\
\hline 0 & 61 & 0 & 0 & 0 & 57 & 42 & 0 & 2 & 32 & 48 & 52 & 1,276 \\
\hline 0 & 36 & 11 & 302 & 509 & 305 & 0 & 16 & 37 & 116 & 169 & 122 & 2,353 \\
\hline 0 & 0 & 0 & 0 & 0 & 0 & & & & & & 18 & 150 \\
\hline 0 & 14 & 0 & 0 & 0 & 0 & 24 & 0 & 93 & 117 & 5 & 34 & 1,264 \\
\hline 0 & 0 & 2 & 0 & 0 & 0 & 0 & 30 & 0 & 22 & 83 & 384 & 584 \\
\hline 0 & 0 & 0 & 0 & 13 & 0 & 8 & 9 & 2 & 0 & 0 & 17 & 76 \\
\hline 246 & 119 & 0 & 0 & 0 & 187 & 0 & 42 & 31 & 0 & 9 & 302 & 1,611 \\
\hline 0 & 0 & 0 & 0 & 0 & 0 & 0 & 0 & 14 & 50 & 0 & 9 & 137 \\
\hline 0 & 0 & 0 & 0 & 64 & 14 & 0 & 10 & 0 & 0 & 0 & 58 & 351 \\
\hline 0 & 13 & 0 & 0 & 332 & 22 & 0 & 0 & 1 & 0 & 0 & 593 & 996 \\
\hline 0 & 0 & 0 & 0 & 0 & 0 & 0 & 0 & 0 & 62 & 8 & 385 & 504 \\
\hline 0 & 17 & 0 & 0 & 0 & 15 & 0 & 0 & 0 & 0 & 81 & 603 & 1,273 \\
\hline 0 & 2 & 0 & 0 & 0 & 0 & 14 & 4 & 7 & 2 & 0 & 8 & 164 \\
\hline 0 & 0 & 0 & 8 & 7 & $<1$ & 429 & 0 & 2 & 7 & 2 & 134 & 588 \\
\hline 6 & 3 & 83 & 4 & 6 & 27 & 250 & 124 & 76 & 117 & 117 & 112 & 1,806 \\
\hline 252 & 276 & 125 & 325 & 932 & 627 & 770 & 267 & 346 & 569 & 541 & 2,900 & 13,596 \\
\hline
\end{tabular}


areas or because of natural reductions in populations on adjacent untreated check a reas. It therefore appears that one cannot depend on anticipated future benefits to amortize treatment costs over a number of seasons.

Table 2 shows the approximate area of rangeland treated for grasshoppers by APHIS from 1956 through 1979 in the 17 western rangeland states. Areas treated by individuals or other agencies are not included. Also, areas that have required a second treatment the same year are not included. During the 24-year period, at least 13.6 million ha were sprayed for grasshopper control, for an average of 0.59 million ha/year. The area with economic infestations (defined by APHIS as 8.75 or more grasshoppers $/ \mathrm{m}^{2}$ ) has always exceeded the area treated. According to APHIS records from 1956-1971, only $9.4 \%$ of the infested area has actually received treatment. In 1979, grasshoppers caused widespread problems, and 2.9 million ha were treated by APHIS. This is only $1 \%$ of the rangeland area in the West. The total area infested again was much greater. than the area treated. Information from 9 states (Colorado, Idaho, Nevada, North Dakota, Oregon, South Dakota, Texas, Utah, Wyoming) showed that only $42 \%$ of the area infested at economic levels was actually treated by APHIS; thus, forage losses in 1979 were probably significant on an additional 4 million ha where control was not attempted.

In cooperative control programs during 1979, the average cost of control on 2.9 million ha was $\$ 2.975 /$ ha. Figure 4 , which is based on data from Table 1, illustrates that the value of forage produced on about 84 million ha (about $32 \%$ of the western range) is worth about $\$ 1.36 /$ ha or less. In those ecosystems, grasshopper control obviously is not economical and cannot be justified by the value of forage that could be protected. It would seem that stocking rates would be maintained at a conservative level so as to avoid serious overgrazing during periods of low forage production and high grasshopper density. Figure 4 also shows that about 18.6 million ha (about $7 \%$ of the western range) produces forage worth more than $\$ 19.75 /$ ha. It is doubtful that control programs would be necessary on such highly productive range because conditions would not be favorable for grasshoppers or forage would be available to maintain both grasshoppers and livestock when grasshoppers are abundant. It therefore appeared that most grasshopper control programs would likely be executed on about 160 million ha (only about $61 \%$ of the western range) that produce forage worth about $\$ 2.50$ to $\$ 7.50 /$ ha.

Precise information on the relationship between forage value and area treated is not readily available because APHIS data are tabulated by state rather than by ecosystem. We therefore decided to compare average forage value per ha per state versus average number of ha treated within the state for a 10-year period,

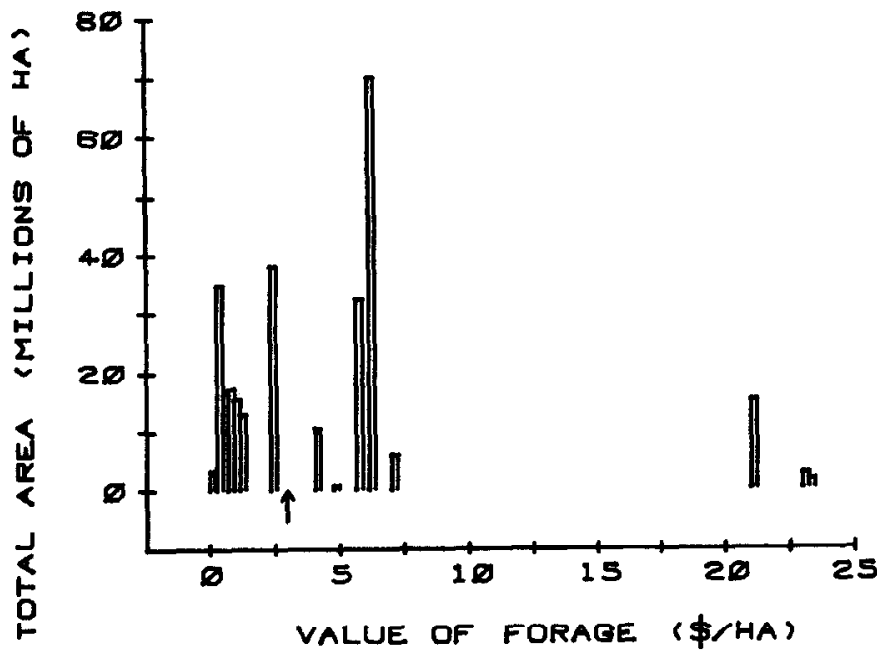

Fig. 4. Relationship between value of forage production/ha and totalarea for the I4 ecosystems listed in Table I (arrow indicates average cost/ha for insecticide treatment).
Table 3. Estimated average forage value per ha of rangeland in western states and average annual area sprayed for grasshopper control during 1970-1979.1

\begin{tabular}{lcc}
\hline \hline State & Avg. value $(\$ /$ ha $)$ & Avg. ha sprayed \\
\hline Ariz. & 1.78 & 26,754 \\
Calif. & 5.80 & 1,729 \\
Colo. & 4.97 & 23,495 \\
Ida. & 3.66 & 155,074 \\
Mont. & 5.80 & 27,149 \\
Neb. & 15.35 & 52,120 \\
Nev. & 2.07 & 4,752 \\
N. Mex. & 3.90 & 57,158 \\
N. Dak. & 7.19 & 7,322 \\
Okla. & 7.88 & 14,585 \\
Ore. & 3.56 & 94,659 \\
S. Dak. & 7.85 & 47,199 \\
Texas & 7.04 & 69,951 \\
Utah & 2.27 & 3,551 \\
Wash. & 5.19 & 58,829 \\
Wyo. & 4.42 & 83,815 \\
\hline
\end{tabular}

'Kansas was not included because of missing data in Table 2 .

1970-1979. Average forage values were calculated from data in Table 1 by summing the products of area times average value for each ecosystem within a state and then dividing by the total area represented. For Nebraska, for example, average value $=3.9$ million ha X\$6.47@+5.8 million ha $\times \$ 21.36 @ \div 9.7$ million ha total $=\$ 15.35 /$ ha. These average forage values are given in Table 3 , along with the average treated area per state, which were calculated from data in Table 2.

There was no overall correlation among data in Table 3 . The data points fell into 3 distinct areas. The 3 states where forage value averaged less than $\$ 2.50 /$ ha (Arizona, Nevada, and Utah) contain $25 \%$ of the western range but only $4.9 \%$ of the treated a rea. That supports the logical hypothesis that grasshopper controls are not applied extensively in areas where controls are not economical. It also raises the possibility that $25 \%$ of the western range could be utilized more efficiently if a cheaper method of grasshopper management were available. At the other extreme, the average per ha value of forage in Nebraska was so high that it had little in common with other states and was rejected from further analysis. Data for the remaining 12 states are plotted in Figure 5. The relationship is described well $(p=0.02)$ by the curvilinear equation, $Y=465-135$ $X+10.3 X^{2}$, where $Y$ is ha treated and $X$ is the average value of forage ( $\$ /$ ha).

The bimodal relationship of Figure 5 suggests some interesting hypotheses on the motivation for control of grasshoppers on

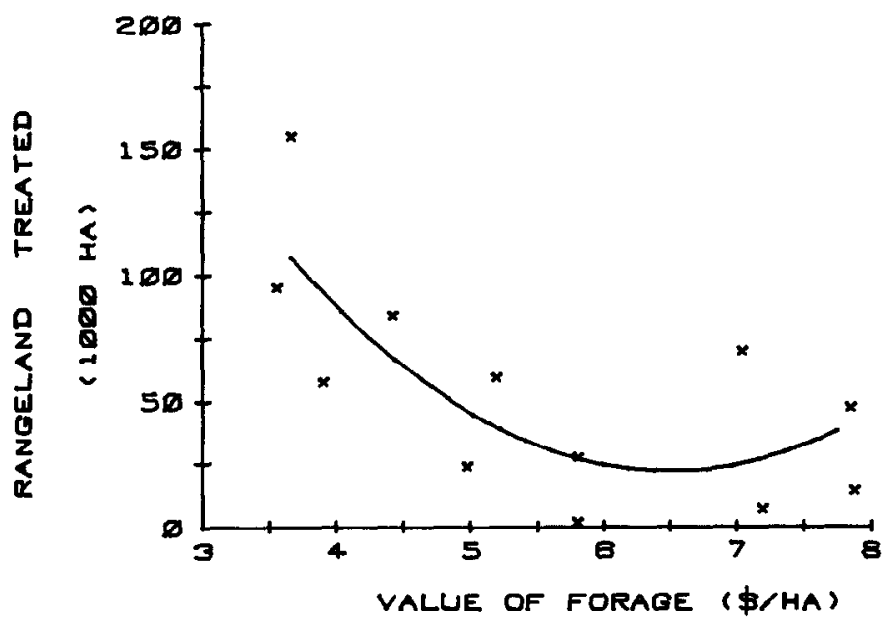

Fig. 5. Relationship between average per-ha value of forage and average area treated annually for grasshoppers during 1970-1979 in 12 western states. 
rangeland. On the most productive range, most of which is in the Great Plains, it appears that grasshopper management could be a lucrative area for investment of capital, especially if high-value cultivated crops are adjacent to or interspersed with rangeland. It is obvious, however, that most of the treatments have been applied to rangeland where the value of forage that potentially can be saved is worth little more than the cost of treatment. This would seem rational only if the treatment option were less expensive than other management alternatives, which include overgrazing, replacement of range forage with hay, and the forced reduction of herds to prevent overgrazing. On some range, therefore, grasshopper control may be the key that stabilizes the livestock industry at stocking rates that are efficient during the majority of seasons when grasshopper populations are not at outbreak levels. If that is true, then the stocking rate on the more productive areas in Arizona, Nevada, and Utah could be permanently increased by development of a method that could manage periodical infestations of grasshoppers at a cost of about $\$ 1.85 /$ ha.

\section{Literature Cited}

Bell, H.M. 1973. Rangeland management for livestock production. Univ. Oklahoma Press, Norman, Okla.

Blickenstuff, C.C., F.E. Skoog, and R.J. Daum. 1974. Long-term control of grasshoppers. J. Econ. Entomol. 67:268-274.

Burleson, W.H., and G.B. Hewitt. 1982. Response of western wheatgrass and needleandthread to defoliation by grasshoppers. J. Range. Manage. 35:223-226.

Clapp, E.H. 1936. The major range problems and their solution, a resume. In the Western Range, USDA, Document No. 199.

Dyer, M.I., and U.G. Bokhari. 1976. Plant-animal interactions, studies of the effects of grasshopper grazing on blue grama grass. Ecology 57:762772
Gage, S.H., M.K. Mukerji, and R.L. Randell. 1976. A predictive model for seasonal occurrence of three grasshopper species in Saskatchewan (Orthoptera: Acrididae). Can. Entomol. 108:245-253.

Hewitt, G.B., W.H. Burleson, and J.A. Onsager. 1976. Forage losses caused by the grasshopper Aulocara elliotti on shortgrass rangeland. J. Range Manage. 29:376-380.

Hewitt, G.B. 1977. Review of forage losses caused by rangeland grasshoppers. ARS Misc. Publ. No. 1348.

Hewitt, G.B. 1978. Reduction of western wheatgrass by the feeding of two rangeland grasshoppers, (Aulocara elliotti and Melanoplus infantilis. J. Eon. Entomol. 71:419-421.

Hewitt, G.B. 1979. Hatching and development of rangeland grasshoppers in relation to forage growth, temperature, and precipitation. Environ. Entomol. 8:24-29.

Hewitt, G.B. 1980. Plant phenology as a guide in timing grasshopper control efforts on Montana rangeland. J. Range Manage. 33:297-299.

Mitchell, J.E., and R.E. Pfadt. 1974. A role of grasshoppers in a shortgrass prairie ecosystem. Environ. Entomol. 3:358-360.

Mukerji, M.K., S.H. Gage, and R.L. Randell. 1977. Influence of embryonic development and heat on population trend of three grasshopper species (Orthoptera: Acrididae) in Saskatchewan. Can. Entomol. 109:229-236.

Mulkem, G.B. 1967. Food selection by grasshoppers. In Annu. Rev. Entomol. 12:59-78.

Onsager, J.A. 1978. Efficacy of carbaryl applied to different life stages of rangeland grasshoppers. J. Econ. Entomol. 71:269-273.

Onsager, J.A., and G.B. Hewitt. 1982. Rangeland grasshoppers: Average longevity and daily rate of mortality among six species in nature. Environ. Entomol. 11:127-133.

Onsager, J.A., N.E. Rees, J.E. Henry, and R.N. Foster. 1980. Integration of bait formulation of Nosema locustae and carbaryl for control of rangeland grasshoppers. J. Econ. Entomol. 74:183-187.

Randell, R.L., and M.K. Mukerji. 1974. A technique for estimating hatching of natural egg populations of Melanoplus sanguinipes (Orthoptera: Acrididae). Can. Entomol. 106:801-812.

USDA, Agricultural Statistics. 1978. USDA Printing Office, Washington, D.C. 